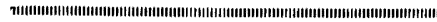

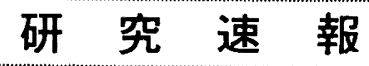

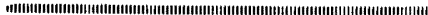

UDC $546.82^{\prime} 171.1: 546.82^{\prime} 221: 546.82^{\prime} 261: 548.7$

\title{
鋼中の $\mathrm{Ti}_{4} \mathrm{X}_{2} \mathrm{~S}_{2}$ 形一炭窒流化物について
}

\author{
成 田 貴
}

\section{Carbo-Nitrogen Sulphide in Steel Containing Titanium}

Synopsis :

Kiichi Narita and Hiroshi Matsumoto

The structure and composition of a titanium carbo-nitrogen sulphide in steels have been determined by means of $\mathrm{X}$-ray diffraction, electron diffraction and electron-probe microanalysis.

The carbo-nitrogen sulphide has a structure similar to that of TiP with a dimension of hexagonal unit cell of $a=3 \cdot 210 \AA, c=11 \cdot 20 \AA$, and $c / a=3 \cdot 49$. Its chemical formula is shown by $\mathrm{Ti}_{4}\left(\mathrm{C}_{m}, \mathrm{~N}_{n}\right)_{2} \mathrm{~S}_{2}$, where $m+n=1$. The ratio of $m$ to $n$ depends on the chemical composition, solidification condition and thermal history of steels.

The carbo-nitrogen sulphide is chemically stable as to be extracted from various steels containing titanium by mineral acid-dissolution and electrolytic methods using these acids, but decomposes gradually in hot mineral acids and oxidizing reagents.

(Received 18, March 1972)

\section{1. 緒臬}

$\mathrm{Ti}$ 法 $\mathrm{C}, \mathrm{N}, \mathrm{O}, \mathrm{S}$ などの非金属元素に対する親和力 の非常に強い元素であり，鋼中では $\mathrm{Fe}$ 格子中に置換型 で固溶しているが，Ti の一部は炭化物，窒化物，酸化物， 硫化物などの化合物を形成し，析出物あるいは介在物 として存在している.これらの化合物のうち，硫化物 については $\left.\mathrm{FeS}-\mathrm{TiS}^{1)}, \mathrm{TiS}^{2) \sim 5)}, \tau-\mathrm{Ti}_{2} \mathrm{~S}^{6)}, \mathrm{Ti}_{4} \mathrm{C}_{2} \mathrm{~S}_{2}{ }^{7}\right)$

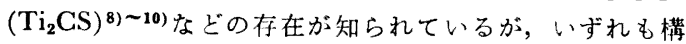
造がかなり複雑であり，かならずしも一致した見解は得 られていない。てこで本報では著者らの実験結果にもと ういて, $\tau-\mathrm{Ti}_{2} \mathrm{~S}$ および $\mathrm{Ti}_{4} \mathrm{C}_{2} \mathrm{~S}_{2}$ 形の化合物に関する所 見を述へ，斯界の参考に供したい。

\section{2. 試料および実験方法}

本実験に使用した試料の化学成分組成を示すと Table 1 のと打りである. 試料AおよびBはステンレス鋼（圧 延材)，試料 $\mathrm{C}$ およびDはマルエイジング鋼（錢造材）で あり, 試料 $\mathrm{E}$ は電解鉄約 $10 \mathrm{~kg}$ を真空誘導融解炉で融解 し， C および Tiを添加してつくつた単純采の試料（鍛 伸材）である.これらの試料を用い，鋼中に認められる 硫化物について EPMA による微小部元素分析, 抽出レ ブリカ法による電子顕微鏡観察ならびに電子線回折，抽 出残査のX線回折などをおこなつた.

\section{3. 実験結果および考察}

本实豎試料中に認められる比較的大きい硫化物の光学 顕微鏡写真ならびに EPMAによる元素分析結果を示す
とてれぞれ Photo. 1 および Table 2 のとおりである. この種の硫化物はその大部分が $\mathrm{N}$ 量の多い Ti-C-N-S 系の化合物であるが， $\mathrm{C}$ 量がやや多く， $\mathrm{C}$ 量に比べて $\mathrm{N}$ 量の比較的少ない試料 Bおよび $\mathrm{E}$ 中には，Table 2 に示 したように C 量のやや多い Ti-C-N-S 系の化合物も認 められる.これらの硫化物は鋼の化学成分組成, 凝固条 件，熱履歴などによつても異なるが，いずれも $\mathrm{Ti}_{2} \mathrm{XS}$ であらわされる基本組成をもつた化合物であり，Xは $\mathrm{C}$ またはNで，両者はたがいに等価で置換しうると考えら れる.なお EPMA による元素分析結果における Fe 量 を考虑すれば， $\mathrm{Ti}$ 原子の格子点の一部に $\mathrm{Fe}$ 原子が位置 していることも考えられ，この場合には $\left(\mathrm{Ti}_{1-x}, \mathrm{Fe}_{x}\right)_{2}$ $\mathrm{XS}$ であらわされ， $x \leq 0.07$ である.

そこでこれらの硫化物の結晶構造を明らかにするた め, $10 \%$ 塩酸を用いて試料を電解し, 抽出した残査につ いてX線回折を試みた。它の結果の一例を示すと Table 3 のとおりであり，BROWN ら6)による $\tau-\mathrm{Ti}_{2} \mathrm{~S}$, GeMmILL ら ${ }^{11)}$ による Y-相および KUdIELKA ら7)による $\mathrm{Ti}_{4} \mathrm{C}_{2} \mathrm{~S}_{2}$ のX線回折結果とよく一致している。また電子顕微鏡に よる観察結果によれば，細長い粒状の化合物あるいは粒 界に棒状の化合物が認められ，これらの化合物の電子線 回折結果も上記 X線回折結果とよく一致している.

BROWN ら ${ }^{6}$ は $18 \% \mathrm{Cr}-8 \% \mathrm{Ni}-\mathrm{Ti}$ 鋼より電解抽出した 残査についてX線回折および化学分析をおこない，残査

* 昭和 45 年 10 月本会講演大会にて発表 昭和 47 年 3 月 18 日受付

** (株) 神戸製鋼所 中央研究所 理博 - 工博

*** (株) 神戸製鋼所 中央研究所 
Table 1. Chemical composition of specimens (\%).

\begin{tabular}{|c|c|c|c|c|c|c|c|c|c|c|c|c|c|c|}
\hline Specimen & C & $\mathrm{Si}$ & $\mathrm{Mn}$ & $\mathbf{P}$ & $\mathrm{S}$ & $\mathrm{Cu}$ & $\mathrm{Ni}$ & $\mathrm{Cr}$ & Mo & Co & $\mathrm{Ti}$ & $\mathrm{Al}$ & $\mathrm{O}$ & $\mathbf{N}$ \\
\hline & & & 1 & 0 & 0 & & & & & & 25 & \multirow{5}{*}{\multicolumn{3}{|c|}{\begin{tabular}{r|r|r}
$0 \cdot 030$ & $0 \cdot 0022$ & 0.0186 \\
$0 \cdot 018$ & 0.0018 & 0.0105 \\
$0 \cdot 106$ & 0.0036 & 0.0056 \\
$0 \cdot 172$ & $0 \cdot 0008$ & 0.0030 \\
- & 0.0029 & 0.0018
\end{tabular}}} \\
\hline & & $0^{\circ}$ & $1 \cdot 61$ & 0 & 0.0 & 0.14 & & & - & & 0.36 & & & \\
\hline C & & $<0.005$ & 0.015 & 0.014 & 0.007 & 0.005 & $17 \cdot 69$ & 0.004 & $4 \cdot 63$ & $11 \cdot 81$ & $1 \cdot 83$ & & & \\
\hline D & & 0.029 & 0.012 & $0 \cdot 003$ & 0.005 & 0.004 & $18 \cdot 08$ & 0.021 & $4 \cdot 63$ & $12 \cdot 05$ & $1 \cdot 82$ & & & \\
\hline & 0 & . & - & & 0.005 & & & & & & 0.18 & & & \\
\hline
\end{tabular}

Table 2. Electron-probe microanalysis of titanium carbo-nitrogen sulphide inclusions*.

\begin{tabular}{|c|c|c|c|c|c|c|c|}
\hline \multicolumn{3}{|c|}{ Inclusion } & $\mathrm{Ti}(\%)$ & $\mathrm{Fe}(\%)$ & C $(\%)$ & $\mathbf{N}(\%)$ & $\mathrm{S} \quad(\%)$ \\
\hline $\begin{array}{l}(\mathrm{a}) \\
(\mathrm{b}) \\
(\mathrm{c}) \\
(\mathrm{d})\end{array}$ & $\begin{array}{c}\text { in Photo. } 1 \\
\text { in Photo. } 1 \\
\text { in Photo. } 1 \\
\text { in Photo. } 1 \\
\text { Photo. 2, } \\
\text { Angular, } \\
\text { Plate-like, } \\
\text { TiS† } \\
\mathrm{Ti}_{2} \mathrm{CS} \dagger \\
\mathrm{Ti}_{2} \mathrm{NS} \dagger \\
\mathrm{Ti}_{2} \mathrm{~S} \dagger\end{array}$ & $\begin{array}{l}\mathrm{A} * * \\
\mathrm{~A} * * \\
\mathrm{C} * * \\
\mathrm{D} * * \\
\mathrm{~B} * * \\
\mathrm{~B} * * \\
\mathrm{E} * *\end{array}$ & $\begin{array}{l}63 \cdot 6 \\
67 \cdot 0 \\
62 \cdot 9 \\
61 \cdot 7 \\
63 \cdot 7 \\
64 \cdot 5 \\
66 \cdot 5 \\
59 \cdot 9 \\
68 \cdot 5 \\
67 \cdot 5 \\
74 \cdot 9\end{array}$ & $\begin{array}{l}3 \cdot 3 \\
0 \cdot 5 \\
5 \cdot 3 \\
5 \cdot 0 \\
5 \cdot 4 \\
4 \cdot 0 \\
2 \cdot 2 \\
- \\
- \\
-\end{array}$ & $\begin{array}{l}0 \cdot 2 \\
0 \cdot 2 \\
0 \cdot 3 \\
0 \cdot 2 \\
0 \cdot 8 \\
1 \cdot 8 \\
3 \cdot 5 \\
-\overline{8 \cdot 6} \\
-\end{array}$ & $\begin{array}{r}8 \cdot 5 \\
8 \cdot 8 \\
9 \cdot 5 \\
9 \cdot 8 \\
9 \cdot 0 \\
8 \cdot 3 \\
7 \cdot 2 \\
- \\
-\overline{9} \cdot 9 \\
-\end{array}$ & $\begin{array}{l}22 \cdot 2 \\
22 \cdot 9 \\
22 \cdot 3 \\
22 \cdot 5 \\
21 \cdot 9 \\
22 \cdot 5 \\
23 \cdot 0 \\
40 \cdot 1 \\
22 \cdot 9 \\
22 \cdot 6 \\
25 \cdot 1\end{array}$ \\
\hline
\end{tabular}

* Silicon, manganese and chromium were not detected.

$\dagger$ Theoretical calculation on the referred compound.

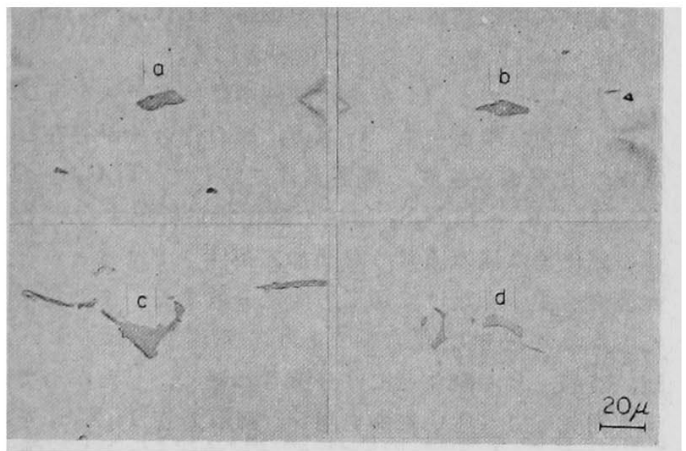

(a), (b) : specimen A, (c) : specimen C, (d) specimen D

Photo. 1. Microstructures of titanium carbo-nitrogen sulphide inclusions.

中の硫化物相をて- $\mathrm{Ti}_{2} \mathrm{~S}$ と名ゔけだ. GemmiLL ら $8 \% \mathrm{Cr}-\mathrm{Mo}-\mathrm{Ti}$ 鋼の電解抽出残査について X 線回折を戈 こない, この鋼中には六方楧造 $(a=3 \cdot 206 \AA, c=11 \cdot 19$ $\AA, c / a=3.49)$ の $\mathrm{Y}$-相が析出し, この相は Ti の窒化 物の変態かあるいは他の化合物であると報告している.

KNOP ${ }^{12)}$ は BROWN および GEMMILL らの実験結果を解 析し, 両相は同じ化合物であり，六方楧造の $\tau-\mathrm{Ti}_{2} \mathrm{~S} て ゙$ あろうと述べている**.いつぽう KUDIELKA ら $\% \mathrm{~S}, 1 \% \mathrm{Ti}$ を含む鉄鉄を塩酸で分解し，その抽出残査

* BROWN らは電解抽出残查中より $\mathrm{Ti}, \mathrm{C}, \mathrm{N}$ および $\mathrm{S}$ を定量し, $\mathrm{N}$ 量より $\mathrm{TiN}$ 形の $\mathrm{Ti}$ 量, $\mathrm{C}$ 量より $\mathrm{TiC}$ 形の $\mathrm{Ti}$ 量を求め, 過剩の $\mathrm{Ti}$ 量と $\mathrm{S}$ 量よりとの残査中の硫化物の組成を計算して $\mathrm{Ti}_{2} \mathrm{~S}$ とし，とれを $\tau$-相とした。

** KNOP は BROWN らわよび GEMMILL らの X 線回折結果の解 析において, $\tau-\mathrm{Ti}_{2} \mathrm{~S}$ および $\mathrm{Y}$-相を正方椿造 $(a=3.92 \AA, c=$ $7 \cdot 43 \AA, c / a=1 \cdot 901)$ と考えてbよく一致すると述へている.

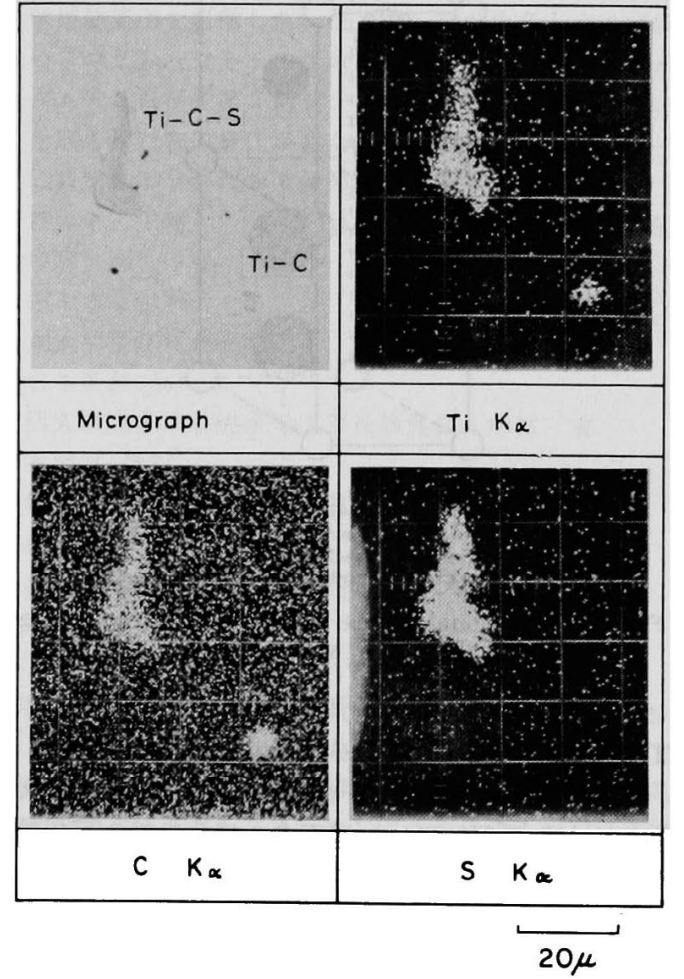

Photo. 2. Scanning images of characteristic X-ray from titanium carbo-nitrogen sulphide in the specimen $B$. 
Table 3. X-ray diffraction data. Recommended unit cell; $a=3 \cdot 210 \AA, c=11 \cdot 20 \AA, c / a=3 \cdot 49$, TiP Type, $D_{o \mathrm{~h}}{ }^{4}-\mathrm{P} 6_{3} / \mathrm{mmc}$.

\begin{tabular}{|c|c|c|c|c|c|c|c|c|c|}
\hline \multicolumn{3}{|c|}{$\mathrm{Ti}_{4} \mathrm{C}_{2} \mathrm{~S}_{2}{ }^{7)}$} & \multicolumn{3}{|c|}{$\tau-\mathrm{Ti}_{2} \mathrm{~S}^{6)}$} & \multicolumn{2}{|c|}{ Residue in A } & \multicolumn{2}{|c|}{ Residue in $\mathrm{E}$} \\
\hline$d(\AA)$ & $I / I_{1}$ & $h k l$ & $d(\AA)$ & $I / I_{1}$ & $h k l$ & $d(\AA)$ & $I / I_{1}$ & $d(\AA)$ & $I / I_{1}$ \\
\hline $2 \cdot 783$ & 50 & $\left(\begin{array}{l}004 \\
100\end{array}\right)$ & $2 \cdot 77$ & 50 & 100 & $2 \cdot 78$ & 30 & $2 \cdot 783$ & 20 \\
\hline $2 \cdot 485$ & 10 & 102 & $2 \cdot 69$ & 20 & 101 & $2 \cdot 49 *$ & 20 & $\begin{array}{l}2 \cdot 713 \\
2 \cdot 496 *\end{array}$ & $\begin{array}{r}5 \\
40\end{array}$ \\
\hline $2 \cdot 225$ & 100 & 103 & $2 \cdot 22$ & 100 & 103 & $2 \cdot 227$ & 100 & $2 \cdot 230$ & 100 \\
\hline $1 \cdot 977$ & 2 & 104 & $1 \cdot 963$ & 20 & 104 & $1 \cdot 974$ & 10 & $1 \cdot 970$ & 5 \\
\hline $1 \cdot 869$ & 50 & 006 & $1 \cdot 859$ & 30 & 006 & $1 \cdot 870$ & 10 & $1 \cdot 869$ & 10 \\
\hline $1 \cdot 606$ & 60 & 110 & $1 \cdot 736$ & 10 & 105 & $1 \cdot 604$ & 30 & $\begin{array}{l}1 \cdot 714 \\
1 \cdot 604\end{array}$ & $\begin{array}{r}5 \\
20\end{array}$ \\
\hline & & & $\begin{array}{l}1 \cdot 596 \\
1 \cdot 542\end{array}$ & $\begin{array}{l}70 \\
50\end{array}$ & $\begin{array}{l}007 \\
112\end{array}$ & $1 \cdot 551$ & 10 & $1 \cdot 552$ & 10 \\
\hline $1 \cdot 536$ & 20 & 106 & & & & & & & \\
\hline $1 \cdot 392$ & 20 & $\left(\begin{array}{l}114 \\
200\end{array}\right)$ & & & & & & $1 \cdot 388$ & 10 \\
\hline $\begin{array}{l}1 \cdot 299 \\
1 \cdot 217\end{array}$ & $\begin{array}{l}50 \\
50\end{array}$ & $\begin{array}{l}203 \\
116\end{array}$ & $\begin{array}{l}1 \cdot 381 \\
1 \cdot 298 \\
1 \cdot 212\end{array}$ & $\begin{array}{l}60 \\
50 \\
50\end{array}$ & $\begin{array}{l}201 \\
203 \\
116\end{array}$ & $\begin{array}{l}1 \cdot 301 \\
1 \cdot 227\end{array}$ & $\begin{array}{l}15 \\
10\end{array}$ & $\begin{array}{l}1 \cdot 283 \\
1 \cdot 217\end{array}$ & $\begin{array}{r}5 \\
10\end{array}$ \\
\hline
\end{tabular}

(Note) Target : Co * Overlapped with diffraction of $\mathrm{TiC}$

Intensities of $\mathrm{Ti}_{4} \mathrm{C}_{2} \mathrm{~S}_{2}$ and $:-\mathrm{Ti}_{2} \mathrm{~S}$ are by visual estimation, and of the residues are by scintillation-counter diffractometer.

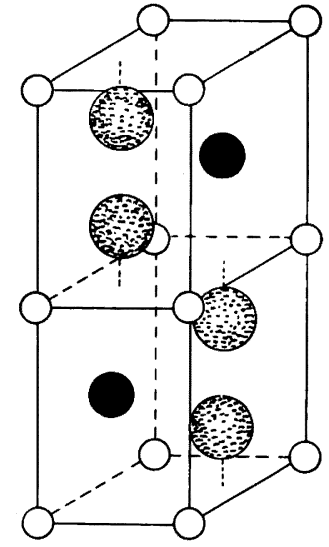

The titanium atoms are largest dotted circles.

The carbon and nitrogen atoms are smallest white circles.

The sulphur atoms are black circles.

$$
a=3 \cdot 210 \AA \quad c=11 \cdot 20 \AA \quad c / a=3 \cdot 49
$$

Fig. 1. Hexagonal lattice of titanium carbo-nitrogen sulphide $\mathrm{Ti}_{4}\left(\mathrm{C}_{m}, \mathrm{~N}_{n}\right)_{2} \mathrm{~S}_{2}$, where $m+n=1$.

についてX線回折おょび化学分析をおこない, 残查中に $\mathrm{TiP}$ 型六方構造の $\mathrm{Ti}_{4} \mathrm{C}_{2} \mathrm{~S}_{2}$ が存在することを示している.

著。者らの $X$ 線および電子線回折結果によれば, 本実験 試料中上り電解抽出した残查中の硫化物相の回折線は Brown, Gemmill，KUdielKa らのいずれの結果とも非 常によく一致しているが, EPMAによる元素分析結果を 考虑すれば，この相は KUDIELKA らが同定した $\mathrm{Ti}_{4} \mathrm{C}_{2} \mathrm{~S}_{2}$ と同一分子種の化合物で，CがNによつて等価置換した $\mathrm{Ti}_{4} \mathrm{X}_{2} \mathrm{~S}_{2}(\mathrm{X} ; \mathrm{C}, \mathrm{N})$ 形の化合物であると考えたほうが妥 当であり，Fig. 1 のような TiP 型六方格子であると考 えられる.このように考劣れば， $\mathrm{C}$ 量の多い銑鉄中に析
出するこの種の硫化物が $\mathrm{Ti}_{4} \mathrm{C}_{2} \mathrm{~S}_{2}$ 組成をとり, BROWN, GemmilL らの実験における詔びゅうが説明でき，また 本実験試料中に認められた硫化物か: $\mathrm{Ti}_{4}\left(\mathrm{C}_{m}, \mathrm{~N}_{n}\right)_{2} \mathrm{~S}_{2}$ 組 成 $(m+n \approx 1)$ をとることが理解される.

いずれにしても $\mathrm{Ti}$ を含む鉄鋼中には黄色味を帯びた 灰色, 黄色, 橙黄色の $\mathrm{Ti}_{4} \mathrm{X}_{2} \mathrm{~S}_{2}$ 形の化合物が存在し, 鉄鋼の化学成分組成, 凝固条件に応じて $\mathrm{Ti}_{4} \mathrm{C}_{2} \mathrm{~S}_{2} \rightarrow \mathrm{Ti}_{4}$ $\left(\mathrm{C}_{m}, \mathrm{~N}_{n}\right)_{2} \mathrm{~S}_{2} \rightarrow \mathrm{Ti}_{4} \mathrm{~N}_{2} \mathrm{~S}_{2}$ 組成の硫化物が析出する。 この 種の硫化物は鋼の通常の熱間加工条件下ではほとえど塑 性变形せず，くだけて加工方向に分散する。また化学的 にもかなり安定な化合物であり，室温下ではうすい䘏 酸, 硫酸, りえ酸などには分解され難く、したがつて還 元雾囲気下でうすい鉱酸を用い，鋼中より $\mathrm{Ti}_{4} \mathrm{X}_{2} \mathrm{~S}_{2}$ を抽 出することができる。しかしながら加熱するか，あるい は酸化性の条件下では徐々に分解する.

\section{交献}

1) 斎藤：鉄と鋼，47 (1961)，p. 707

2 ) 有川, 成田: 鉄と鋼, 39 (1953), p. 352

3 ) 金子, 西沢, 玉置: 日本金属学会誌, 24 (1960), p. 837

4 ) 加納, 時実, 盛: 鉄と鋼, 49 (1963), p. 540

5 ) 田上, 池田：鉄と鋼，50 (1964), p. 182

6 ) J.F. Brown, $W . D$. Clark, and $A$. Parker: Metallurgia, 56 (1957), p. 215

7 ) $H$. KUDIELKA and H. ROHDE: Z. Krist., 114 (1960), p. 447

8 ) 成田, 尾上, 岩本: 日本鉄鋼協会第 75 回春季講 演大会にて発表 (1968)

9 ）成田: 日本金属学会会報, 7 (1968), p. 742

10）成田，宮本，松本：鉄と鋼，58 (1972)， p. 482

11) $M$. G. Gemmill, $H$. Hughes, $J . D$. Murray, $F$. B. Pickering, and $K . W$. Andrews: JISI, 184 (1956), p.' 122

12) O. KNop: Metallurgia, 57 (1958), p. 137 